Review Article

\title{
An Ephemeral Review on Pulmonary Arterial Hypertension
}

\author{
Akshima Gupta, Kanaparthi Sushrutha, Nikhil Kumar Vanjari* \\ Department of Clinical Pharmacy, Vaageswari College of Pharmacy, Karimnagar, Telangana, India \\ Email address: \\ nikhi171311@gmail.com (N. K. Vanjari) \\ ${ }^{*}$ Corresponding author
}

To cite this article:

Akshima Gupta, Kanaparthi Sushrutha, Nikhil Kumar Vanjari. An Ephemeral Review on Pulmonary Arterial Hypertension. American Journal of Internal Medicine. Vol. 7, No. 4, 2019, pp. 81-85. doi: 10.11648/j.ajim.20190704.11

Received: May 23, 2019; Accepted: June 25, 2019; Published: July 9, 2019

\begin{abstract}
Pulmonary arterial hypertension $[\mathrm{PAH}]$ is a rare and potentially fatal disease whose management is usually restricted to a few specialized centers. The crucial vascular modifications in pulmonary arterial hypertension are endothelial-cell proliferation, vasoconstriction, thrombosis and smooth-muscle cell. As patients don't essentially board in the neighborhood to those centers, daily care and emergencies ought to be delegated to the primary and second lines. Reduced contractility of mycardium, decreased venous return and abnormal rate of exchange of gases leads to deprivation of oxygen to cell and death. Diagnosing and management of pulmonary arterial hypertension is critical. There is no cure for PAH. Modern developments regarding cell biology, molecular genetics and of idiopathic pulmonary arterial hypertension create new insights and therapeutic targets in the management. However, there are several treatment options that aim to reduce symptoms, improve the quality of life, and slow disease progression. This short review provides an outline of our therapeutic protocols supported out there information. Based on the analysis of the reasons for death in the PAH population, a review of the main emergencies is provided. Drugs include vasodilators, anticoagulants, antiplatelet agents, antiinflammatory therapies, and vascular-remodeling therapies. Most of the drugs have pleiotropic effects.
\end{abstract}

Keywords: Pulmonary Arterial Hypertension, Nitric Oxide, Hypoxemia, Thromboembolism, Vasopressors

\section{Introduction}

Pulmonary high blood pressure $[\mathrm{PH}]$ consists of a bunch of diseases with a resting mean pulmonic artery pressure [mPAP] $25 \mathrm{mmHg}$ as measured with a right heart catheterization [1]. PH is considered a rare disease [2]. In $\mathrm{PAH}$, the pre-capillary arterioles are affected by an angioproliferative vasculopathy that increases the pulmonary vascular resistance, thereby increasing the right ventricular afterload with the resulting right heart failure being the ultimate cause of mortality. Patients exhibit pathological changes which include enhanced pulmonary arteriole contractility, endothelial dysfunction, remodeling and proliferation of both endothelial and smooth muscle cells [3].

\section{Pathogenesis of Pulmonary Arterial Hypertension}

\subsection{Nitric Oxide Pathway}

Inhaled nitric oxide gas can alleviate vasoconstriction and may modulate cellular proliferative responses. [4] Nitric oxide is produced in endothelial cells by eNOS, which, in the presence of oxygen. NADPH and other cofactors catalyze the oxidation of L-arginine to L-citrulline. Nitric Oxide diffuses into the underlying pulmonary vascular smooth muscle cells [PVSMC] and binds to soluble guanylate cyclase [sGC], which in turn, converts guanosine triphosphate [GTP] to cyclic guanosine monophosphate [cGMP]. The subsequent activation of downstream cGMP-dependent protein kinases $[\mathrm{PKG}]$ results in pulmonary vasodilatation. Additionally, NO 
inhibits PVSMC proliferation, platelet aggregation, and thrombosis, maintaining normal healthy pulmonary vasculature $[5,6]$.

\subsection{Prostacyclin - Thromboxane $A_{2}$ Pathway}

This pathway is activated once $\mathrm{PGI}_{2}$ stimulates the IP receptor, resulting in increased cyclic adenosine monophosphate and leading to vasodilatory and antiproliferative effects [7]. An increase in the release of the vasoconstrictor thromboxane $A_{2}$ leads to the activation of platelets in both primary and secondary forms of pulmonary hypertension [8].

\subsection{Endothelin-1 Pathway}

ET-1 is a peptide that acts as a potent vasoconstrictor. [9] It has two types of receptors $\mathrm{ET}_{\mathrm{A}}$ and $\mathrm{ET}_{\mathrm{B}}$. $\mathrm{ET}_{\mathrm{A}}$ is present in smooth muscle cells and $\mathrm{ET}_{\mathrm{B}}$ are localized in both endothelial and smooth muscle cells. Activation of $\mathrm{ET}_{\mathrm{A}}$ and
$\mathrm{ET}_{\mathrm{B}}$ receptors on smooth muscle cells mediates the vasoconstrictive and mitogenic effects of ET-1. Stimulation of endothelial $\mathrm{ET}_{\mathrm{B}}$ receptor promotes ET-1 clearance and activation of prostacyclin release [10].

\section{Risk Factors}

It is a rare disease, which can be sporadic or clustered in families. Genetic studies identified mutations in the bone morphogenetic protein-2 [BMPR-2] gene, a receptor member of the transforming growth factor- $\beta$ family, i9n most familial cases of PAH. Other vascular processes included are a vasoconstrictor-vasodilator imbalance, thrombosis, misguided angiogenesis, and inflammation. Drugs, chemical products, diseases, obesity, altitude, age, gender may also be associated with the risk factor [12]. Complications include Right heart enlargement, Blood clots, Irregular heartbeats, Coughing up blood [13].

Table 1. Revised WHO Groups for Pulmonary Hypertension [11].

\begin{tabular}{ll}
\hline Group & Examples \\
\hline Group 1: Pulmonary Arterial Hypertension & Familial, idiopathic PAH, HIV, drug induced, congenital heart \\
Group 2: Pulmonary Hypertension caused by left-sided heart disease & Disease Must exclude other secondary causes of PH to diagnose PAH \\
Group 3: Pulmonary Hypertension caused by lung disease or hypoxemia & Chronic LV failure, severe mitral valve disease, severe aortic valve disease \\
Group 4: Pulmonary Hypertension from chronic thromboembolic or & Previous PE, especially recurrent PEs, large PEs, extremes of age, or PH at \\
embolic disease & diagnosis of PE Up to 30\% of patients may not have had a previous PE \\
Group 5: Miscellaneous & Mediastinal tumors or adenopathy, sarcoidosis, hemodialysis, thyroid \\
\hline
\end{tabular}

COPD-chronic obstructive pulmonary disease, LV- left ventricular, PE- pulmonary embolus, PAH-Pulmonary Arterial Hypertension, OSA- obstructive sleep apnea, PH- Pulmonary Hypertension.

\section{Clinical Presentation}

Symptoms are unspecific, so there is often delay of many months or even years between the onset of symptoms and diagnosis. With the progression of a disease, the symptoms become worse and new symptoms occur. Dyspnea on bending down, Syncope even on slight exertion, Fatigue, Weakness, Decreased exercise tolerance, Dizziness, low blood pressure, fast heart rate, chest pressure, swollen legs [14].

\section{Treatment and Management}

Two decades past, patients with idiopathic PAH had a dismal median survival rate from diagnosis of, $<3$ yrs, despite available supportive treatment. There is no cure for $\mathrm{PAH}$; however, there are several treatment options that aim to reduce symptoms, improve the quality of life, and slow disease progression [15]. Eight drugs belonging to three pharmacological classes [endothelin receptor antagonists, phosphodiesterase type-5 inhibitors and prostanoids] are approved which are administered by subcutaneous, intravenous inhaled, andoral. None of these therapies is curative, but they contributed to allowing PAH to evolve from a uniformly fatal condition to chronic disease in some cases [16].

Table 2. Management considerations [17].

\begin{tabular}{ll}
\hline PH & ED Management \\
\hline RV failure in PAH & $\begin{array}{l}\text { Continue/resume pulmonary vasodilator regimen, especially in cases of pump malfunction. Early consultation with PH specialist. } \\
\text { Consider pulmonary or cardiology or emergency consultation if PH specialist is unavailable. Consider early transfer for } \\
\text { [group 1] }\end{array}$ \\
$\begin{array}{l}\text { mechanical support, including RVAD or ECMO. Consider volume overload, as indicated provide hemodynamic support with } \\
\text { vasopressors, pulmonary vasodilators, and inotropes. }\end{array}$ \\
$\begin{array}{l}\text { Aggressively treat the underlying condition, such as diuresis for PH from left-sided heart failure Treat respiratory acidosis and } \\
\text { types of PH [groups 2- } \\
\text { 5] }\end{array}$ & $\begin{array}{l}\text { hypoxemia, consider bronchodilators for COPD in PAH. Consider first-line agent norepinephrine. Early consultation with } \\
\text { cardiologist, pulmonologist, or PH specialist. Consider mechanical support early with RVAD or ECMO For CTEPH patients, } \\
\text { consider pulmonary endarterectomy in an emergency. }\end{array}$ \\
\hline
\end{tabular}

PAH-Pulmonary arterial hypertension; RVAD- right ventricular assist device; ECMO- extracorporeal membrane oxygenation; CTEPH- Chronic Thrombo Embolism Pulmonary Hypertension. 
a) Pulmonary hypertension should be considered in any ED patient with unexplained dyspnea exertion, syncope, or signs of right ventricular dysfunction. Patients with a history of pneumonic emboli who present with dyspnea and no explanation on ED testing should be considered at risk for chronic thromboembolism pulmonary hypertension. [18]

b) Chest computed tomography [CT] may demonstrate evidence of pulmonary hypertension [19]. Pulmonary artery dilatation on CT correlates well with pulmonary artery pressure and $\mathrm{CT}$ scans can evaluate the right ventricular size and detect interventricular septal bowing. Enlargement of the right ventricle to greater than nine-tenths of the size of the LV by CT scan correlates with an increased risk of adverse events and death in patients with acute pulmonary emboli [20-24].

c) Systemic hypotension should be avoided. The cardiac output in most patients with advanced pneumonic high blood pressure cannot be increased due to "fixed" pneumonic tube resistance. Therefore, any reduction in systemic vascular resistance [SVR] will not be followed by a compensatory increase in cardiac output, thus magnifying the degree of hypotension. In addition, as described above, as the right ventricular pressures approach systemic arterial pressures, right coronary perfusion will decrease [25].

d) Norepinephrine offers several advantages in the emergency care of these patients. It is of proven benefit in several types of shock, especially septic shock. It helps maintain coronary perfusion pressure and slightly augment inotropy [26-28].

e) On balance, especially if a component of distributive shock is suspected, norepinephrine is an appropriate first-line vasopressor despite potential increases in pulmonary vascular resistance from a stimulation.

f) Phenylephrine should be avoided in patients with pulmonary hypertension because of increases of the pulmonary vascular resistance, whereas vasopressin may actually decrease pulmonary vascular resistance through a nitric oxide-based mechanism [29-32]. Although dobutamine increases cardiac output, it has 2 major disadvantages of increased tachycardia [33] and decreased SVR, limiting its use as a single agent because of the risk of systemic hypotension [31].

Table 3. Pulmonary Vasodilators And Emergency Considerations [34-36].

\begin{tabular}{|c|c|c|c|}
\hline Class of Medication & Delivery & Mechanism of action & Emergency considerations \\
\hline iNO & Inhalation & $\begin{array}{l}\text { Relaxes vascular smooth } \\
\text { muscle Inhibits platelet } \\
\text { aggregation }\end{array}$ & $\begin{array}{l}\text { Not used as long-term therapy in PAH May be employed in severe } \\
\text { RV failure, massive pulmonary embolism Will decrease PVR; } \\
\text { minimal effects on SVR Will improve V/Q mismatch }\end{array}$ \\
\hline $\begin{array}{l}\text { Prostacyclins. } \\
\text { Epoprostenol [Flolan, } \\
\text { Veletr] Treprostinil } \\
\text { Iloprost }\end{array}$ & $\begin{array}{l}\text { Intravenous, } \\
\text { inhalation. } \\
\text { Intravenous, inhaled, } \\
\text { subcutaneous. Inhaled }\end{array}$ & $\begin{array}{l}\text { Relaxes vascular smooth } \\
\text { muscle }\end{array}$ & $\begin{array}{l}\text { Intravenous formulations may be used as long-term therapy in PAH. } \\
\text { Sudden withdrawal can lead to rebound PH May be used rather than } \\
\text { iNO for severe RV failure Will decrease each SVR and PVR if given } \\
\text { intravenously Will decrease solely PVR if inhaled can worsen V/Q } \\
\text { twin if given intravenously; will improve V/Q mismatch if inhaled }\end{array}$ \\
\hline $\begin{array}{l}\text { Endothelin receptor } \\
\text { antagonists-Bosentan } \\
\text { Macitentan Ambrisentan }\end{array}$ & oral & $\begin{array}{l}\text { Inhibits the } \\
\text { vasoconstrictive properties } \\
\text { of endothelin }\end{array}$ & $\begin{array}{l}\text { Used as long-term therapy in PAH Minimal emergency use Patients } \\
\text { ought to still receive this medication unless changes prescribed by } \\
\text { PH specialist }\end{array}$ \\
\hline $\begin{array}{l}\text { PDE-5 inhibitors, } \\
\text { sildenafil, tadalafil }\end{array}$ & Oral, intravenous & $\begin{array}{l}\text { Block degradation of } \\
\text { cyclic guanosine } \\
\text { monophosphate to allow } \\
\text { vascular smooth muscle } \\
\text { relaxation }\end{array}$ & $\begin{array}{l}\text { Used as long-term therapy in PAH Minimal emergency usePatients } \\
\text { should continue to receive this medication unless changes prescribed } \\
\text { by hydrogen ion concentration specialist }\end{array}$ \\
\hline
\end{tabular}

iNO, Inhaled nitric oxide; V/Q, ventilation-perfusion; PDE, phosphodiesterase.

Continuous positive airway pressure is a well-established treatment for patients with obstructive sleep apnea and pulmonary hypertension, and bilevel positive airway pressure has demonstrated excellent outcomes in chronic obstructive pulmonary disease and congestive heart failure [37].

If intubation and mechanical ventilation are unavoidable, hypotension and loss of right ventricular contractility must be prevented [38].

\section{Conclusion}

The emergency care of unstable $\mathrm{PAH}$ patient requires immediate and closed collaboration between critical care experts and PAH experts. Substantial advancements in the understanding and management of PAH have been made. The current understanding of PAH etiology includes nitric oxide, prostacyclin-thromboxane, and endothelin-1 pathways. There are five classes of drugs that target specifically phosphodiesterase-5 inhibitors, endothelin receptor antagonists, prostacyclin receptor agonists, prostacyclin analogs and soluble guanylate cyclase inhibitors. Recent long-term trials have shown evidence of progression-free survival with an initial, or early, the addition of these drugs, either in isolation or in combination with other drug classes.

\section{References}

[1] Hoeper, M. M.; Bogaard, H. J.; Condliffe, R.; Frantz, R.; Khanna, D.; Kurzyna, M.; Langleben, D.; Manes, A.; Satoh, T.; Torres, F. Definitions and diagnosis of pulmonary hypertension. J. Am. Coll. Cardiol. 2013, 62, D42-D50. 
[2] Moreira, E. M.; Gall, H.; Leaning, M. J.; Lahousse, L.; Loth, D. W.; Krijthe, B. P.; Kiefte-de Jong, J. C.; Brusselle, G. G.; Hofman, A.; Stricker, B. H. Prevalence of pulmonary hypertension in the general population: The Rotterdam study. PLoS ONE 2015, 10, e0130072.

[3] Tuder, R. M.; Archer, S. L.; Dorfmüller, P.; Erzurum, S. C.; Guignabert, C.; Michelakis, E.; Rabinovitch, M.; Schermuly, R.; Stenmark, K. R.; Morrell, N. W. Relevant issues in the pathology and pathobiology of pulmonary hypertension. J. Am. Coll. Cardiol. 2013, 62, D4-D12.

[4] Lundberg JO, Weitzberg E, Gladwin MT. The nitrate-nitrite-nitric oxide pathway in physiology and therapeutics. Nature Reviews Drug Discovery. 2008; 7: 156167.

[5] Giaid, A.; Saleh, D. Reduced expression of endothelial nitric oxide synthase in the lungs of patients with pulmonary hypertension. N. Engl. J. Med. 1995, 333, 214-221.

[6] Zhao, Y.-Y.; Zhao, Y. D.; Mirza, M. K.; Huang, J. H.; Potula, H.-H. S.; Vogel, S. M.; Brovkovych, V.; Yuan, J. X.-J.; Wharton, J.; Malik, A. B. Persistent Enos activation secondary to caveolin-1 deficiency induces pulmonary hypertension in mice and humans through pkg nitration. J. Clin. Investig. 2009 $119,2009-2018$.

[7] Mubarak KK. A review of prostaglandin analogs in the management of patients with pulmonary arterial hypertension. Respir Med 2010; 104: 9-21.

[8] Christman BW, McPherson CD, Newman JH, King GA, Bernard GR, Groves BM, Loyd JE. An imbalance between the excretion of thromboxane and prostacyclin metabolites in pulmonary hypertension. New England Journal of Medicine. 1992 Jul 9; 327 [2]: 70-5.

[9] Yanagisawa, M.; Kurihara, H.; Kimura, S.; Tomobe, Y.; Kobayashi, M.; Mitsui, Y.; Yazaki, Y.; Goto, K.; Masaki, T. A novel potent vasoconstrictor peptide produced by vascular endothelial cells. Nature 1988, 332, 411-415.

[10] Galié N, Manes A, Branzi A. The endothelin system in pulmonary arterial hypertension. Cardiovascular research. 2004 Feb 1; 61 [2]: 227-37.

[11] Hoeper MM. Definition, classification, and epidemiology of pulmonary arterial hypertension. seminars in respiratory and critical care medicine 2009 Aug [Vol. 30, No. 04, pp. 369-375].

[12] Humbert $M$, Nunes $H$, Sitbon $O$, Parent F, Hervé $P$, Simonneau G. Risk factors for pulmonary arterial hypertension. Clinics in chest medicine. 2001 Sep 1; 22 [3]: 459-75.

[13] Simonneau G, Galiè N, Rubin LJ, Langleben D, Seeger W, Domenighetti G, Gibbs S, Lebrec D, Speich R, Beghetti M, Rich S. Clinical classification of pulmonary hypertension. Journal of the American College of Cardiology. 2004 Jun 16; 43 [12 Supplement]: S5-12.

[14] Bazan IS, Fares WH. Pulmonary hypertension: diagnostic and therapeutic challenges. Therapeutics and clinical risk management. 2015; 11: 1221.

[15] Naeije R. Treatment of right heart failure on pulmonary arterial hypertension: is going left a step in the right direction? Eur Respir Rev 2010; 19: 4-6.
[16] Galie N, Palazzini M, Manes A. Pulmonary arterial hypertension: from the kingdom of the near-dead to multiple clinical trial meta-analyses. Eur Heart J 2010; [Epub ahead of print DOI: 10.1093/ our heart/ehq152].

[17] Minai OA, Yared JP, Kaw R, et al. Perioperative risk and management in patients with pulmonary hypertension. Chest. 2013; 144: 329-340.

[18] Brown LM, Chen H, Halpern S, et al. Delay in recognition of pulmonary arterial hypertension: factors identified from the REVEAL registry. Chest. 2011; 140: 19-26.

[19] Dela Cruz M, Devey JS. Emergency department diagnosis of pulmonary hypertension in a patient with left atrial sarcoma. Int J Emerg Med. 2014; 7: 32-014-0032-5.

[20] Devaraj A, Wells AU, Meister MG, et al. Detection of pulmonary hypertension with multidetector CT and echocardiography alone and in combination. Radiology. 2010; 254: 609-616.

[21] Grubstein A, Benjaminov O, Dayan DB, et al. Computed tomography angiography in pulmonary hypertension. Isr Med Assoc J. 2008; 10: 117-120.

[22] Raman SV, Shah M, McCarthy B, et al. Multi-detector row cardiac computed tomography accurately quantifies right and left ventricular size and function compared with cardiac magnetic resonance. Am Heart J. 2006; 151: 736-744.

[23] Quiroz R, Kucher N, Schoepf UJ, et al. Right ventricular enlargement on chest computed tomography: prognostic role in acute pulmonary embolism. Circulation. 2004; 109: 2401-2404.

[24] Schoepf UJ, Kucher N, Kipfmueller F, et al. Right ventricular enlargement on chest computed tomography: a predictor of early death in acute pulmonary embolism. Circulation. 2004; 110: 3276-3280.

[25] Maxwell BG, Pearl RG, Kudelko KT, et al. Case 7-2012. Airway management and perioperative decision making in the patient with severe pulmonary hypertension who requires emergency noncardiac surgery. J Cardiothorac Vasc Anesth. 2012; 26: 940-944.

[26] De Backer D, Boston P, Devriendt J, et al. Comparison of dopamine and norepinephrine in the treatment of shock. N Engl J Med. 2010; 362: 779-789.

[27] De Backer D, Aldecoa C, Njimi H, et al. Dopamine versus norepinephrine in the treatment of septic shock: a meta-analysis. Crit Care Med. 2012; 40: 725-730.

[28] Dellinger RP, Levy MM, Rhodes A, et al. Surviving Sepsis Campaign: international guidelines for the management of severe sepsis and septic shock: 2012. Crit Care Med. 2013; 41: 580-637.

[29] Rich S, Gubin S, Hart K. The effects of phenylephrine on right ventricular performance in patients with pulmonary hypertension. Chest. 1990; 98: 1102-1106.

[30] Kwak YL, Lee CS, Park YH, et al. The effect of phenylephrine and norepinephrine in patients with chronic pulmonary hypertension. Anesthesia. 2002; 57: 9-14.

[31] Price LC, Wort SJ, Finney SJ, et al. Pulmonary vascular and right ventricular dysfunction in adult critical care: current and emerging options for management: a systematic literature review. Crit Care. 2010; 14: R169. 
[32] Currigan DA, Hughes RJ, Wright CE, et al. Vasoconstrictor responses to vasopressor agents in human pulmonary and radial arteries: an in vitro study. Anesthesiology. 2014; 121: 930-936.

[33] Hoeper MM, Granton J. Intensive care unit management of patients with severe pulmonary hypertension and right heart failure. Am J Respir Crit Care Med. 2011; 184: 1114-1124.

[34] Lahm T, McCaslin CA, Wozniak TC, et al. Medical and surgical treatment of acute right ventricular failure. J Am Coll Cardiol. 2010; 56: 1435-1446.

[35] Lopez BL, Christopher TA, Griswold SK, et al. Bench to bedside: nitric oxide in emergency medicine. Acad Emerg Med. 2000; 7: 285-293.
[36] Frostell CG, Blomqvist H, Hedenstierna G, et al. Inhaled nitric oxide selectively reverses human hypoxic pulmonary vasoconstriction without causing systemic vasodilation. Anesthesiology. 1993; 78: 427-435.

[37] Ismail K, Roberts K, Manning P, et al. OSA and pulmonary hypertension: time for a new look. Chest. 2015; 147: 847-861.

[38] Maxwell BG, Pearl RG, Kudelko KT, et al. Case 7-2012. Airway management and perioperative decision making in the patient with severe pulmonary hypertension who requires emergency noncardiac surgery. J Cardiothorac Vasc Anesth. 2012; 26: 940-944. 